\title{
Semeando os alicerces da nação: História, nacionalidade e cultura nas páginas da revista Niterói
}

Sowing the grounds of the nation: History, nationality and culture on the pages of the Niterói review

Débora El-Jaick Andrade*

\section{Resumo}

Redigida por estudantes brasileiros residentes em Paris - Domingos José Gonçalves de Magalhães, Manuel Araújo Porto Alegre e Francisco Sales Torres Homem -, a revista Niterói (1836) manifestava o propósito das revistas literárias do século XIX de fomentar o amor à literatura, às artes e às ciências, e se nutriu do contato dos seus redatores com a intelectualidade francesa e com as novas ideias filosóficas que triunfaram no período. Com base nas memórias apresentadas nas sessões do Institut Historique de Paris, na correspondência dos autores e nos artigos da revista Niterói, buscamos reconstituir a proposta de afirmação da nacionalidade realizada através dos preceitos do historicismo, demonstrando que as artes e a literatura eram entendidas como alicerces sobre os quais a nação deveria se edificar para concretizar sua independência.

Palavras-chave: historiografia; historicismo; imprensa.

\section{Abstract}

The Niterói (1836), a review published by young Brazilian students living in Paris - Domingos José Gonçalves de Magalhães, Manuel Araújo Porto Alegre, and Francisco Sales Torres Homem - , expressed the inclination of major literary reviews in the $19^{\text {th }}$ century, which was to stimulate enthusiasm for literature, arts and sciences. It profited from the contact established between its editors and French intellectuals, as much as from philosophical ideas that triumphed at the time. By analyzing memoirs, letters and essays published at the Niterói, we wished to recognize the proposition of its publishers of confirming nationality through the precept of historicism. It shows that arts and literature were perceived as grounds upon which the nation should be built in order to accomplish its independence. Keywords: historiography; historicism; press.

\footnotetext{
* Professora adjunta da área de Teoria e Metodologia da História. Curso de História, Centro de Ciências Humanas Educação e Letras, Universidade Estadual do Oeste do Paraná. Rua Pernambuco, 1777, Centro. 85960-000 Marechal Cândido Rondon - PR - Brasil. deb-eljaick@ uol.com.br
} 
No plano cultural internacional, a década de 1830 marcou uma série de transformações na imprensa periódica e na literatura. Na Europa, em especial na França, ocorria uma semirrevolução técnica que permitiu a expansão do público leitor nos limites impostos pelos níveis de alfabetização e meios de distribuição, com base na redução dos custos de produção. ${ }^{1} \mathrm{O}$ aumento considerável das tiragens promoveu o êxito da imprensa cotidiana, de jornais como La Presse de Émile Girardin e Le Siècle de Armand Dutacq, cuja sobrevivência passou a depender da publicidade e da sedução exercida pelo romance folhetim sobre um público leitor mais 'popular'. A partir de então, o romance folhetim francês, reproduzido e traduzido mundo afora, impactou as literaturas nacionais, o modo de trabalho e o prestígio social dos escritores.

Além de se constituir em um instrumento de poder na luta política e eleitoral, a imprensa abria espaço às revistas literárias, cujas primeiras versões remontam ao século XVII. Na França, durante a Monarquia de Julho (18301848), surgiram revistas inspiradas nos modelos ingleses que abordavam grande variedade de temas, tanto políticos como científicos, artísticos e especialmente literários, inserindo em suas páginas poemas, romances, novidades, textos e fragmentos, comentários e resenhas. A mais importante a surgir em 1829, pouco antes do arrefecimento da censura que levou tantos periódicos a desaparecerem, foi a Revue de Litterature, Histoire, Arts et Sciences des Deux Mondes, que trazia uma diversidade de temas voltados à instrução dos leitores: diário de viagens, administração, costumes entre povos diferentes e novidades sobre o progresso da civilização (Charle, 2004, p.63). Após algumas reformulações, seu conteúdo se tornou mais cultural e literário. A Revue constituiu como um de seus objetivos reunir os melhores escritores, historiadores e políticos, tais como Victor Hugo, Alexandre Dumas, Jules Michelet, Charles A. Sainte-Beuve, Honoré de Balzac e George Sand (Charle, 2004, p.64).

As revistas literárias assumiram importante papel no debate estético e literário que conduziu à afirmação do romantismo, como demonstram as polêmicas a respeito da doutrina romântica e da renovação literária travadas em diferentes momentos por Minerve Littéraire, Muse Française e Le Globe. A valorização de um ideal estético não era de todo incompatível com os ideais e posicionamentos políticos. Longe disso, a busca pela emancipação da prática artística e literária era equiparada por muitos representantes do romantismo à emancipação civil e social. ${ }^{2}$ Além disso, torna-se importante ressaltar que a grande incidência dos periódicos literários e artísticos na França sob a Restauração se explica pela maior probabilidade de estes escaparem da censura à 
imprensa comum e garantirem a publicação de artigos com conteúdo indiretamente político (Charle, 2004, p.33).

Também em Portugal, multiplicaram-se as revistas literárias, especialmente durante a afirmação da imprensa entre 1836 e 1840. Ao mesmo tempo continuadoras do espírito iluminista e do propósito literário, instrutivo e enciclopédico das revistas precedentes, inovavam por colocar em pauta o debate sobre a renovação da literatura setecentista portuguesa. ${ }^{3}$ Alguns dos mais famosos periódicos literários foram: o Repositório literário da sociedade das Ciências Médicas e de literatura do Porto (1834-1835) e O Panorama, jornal literário e instrutivo (1837-1868), dirigido por Alexandre Herculano. Permeáveis aos modelos estrangeiros, sobretudo da França, revistas como O Panorama divulgavam a obra de autores franceses, como Germaine de Stäel, e passaram a adotar a fórmula do folhetim.

No Brasil, diferentemente da Europa, o período de turbulências políticas no Primeiro Reinado e das Regências retardou em algumas décadas a multiplicação das revistas divulgadoras das ciências, das artes e da literatura. Elas não se afirmariam antes do apaziguamento das lutas políticas e da consolidação da monarquia sob o Segundo Reinado. Ocorria, então, a predominância do jornalismo político, iniciada com os embates que levaram à Independência e continuada na década de 1830, com a partidarização da imprensa, que no período regencial girava em torno dos projetos de organização do poder na nova nação, envolvendo e fomentando rivalidades entre exaltados, moderados e caramurus. Jornais e periódicos pretendiam intervir diretamente sobre a vida política, defendendo ideários políticos e assumindo o papel de formadores de opinião.

A revista Niterói, redigida em Paris no ano de 1836, anunciava como objetivo desviar-se das acaloradas disputas partidárias que ocupavam grande parte da imprensa no período regencial. Divergindo da tendência dos pasquins e das folhas das décadas de 1820 e 1830, sua proposta, contudo, seguia a lógica do liberalismo moderado expressa por Evaristo da Veiga, redator da Aurora Fluminense, amigo dos redatores Sales Torres Homem e Araújo Porto Alegre. Estes consideravam perigosos os conflitos, a desordem e seus efeitos sobre a sociedade, que deveria ser preservada do choque violento entre os partidos. ${ }^{4}$ Não foi a única, nem a primeira, a trazer em suas páginas preocupações literárias, científicas e informativas, pois revistas com esse perfil existiram de forma fugaz desde o período joanino. ${ }^{5}$ Sua singularidade, expressa na proposta dos seus redatores, é de que, ao mesmo tempo em que se aproximava do modelo das revistas literárias do início do século XIX, trazendo as novidades es- 
téticas e informações úteis, propunha-se a ser formadora de opinião, despertando a atenção para assuntos polêmicos e de fundo político. Como explicita a apresentação do primeiro tomo, sua intenção era "desviar-se das habituais discussões sobre cousas de pouca utilidade, e o que é mais, de questões sobre a vida privada dos cidadãos, que os acostumasse a refletir sobre objetos do bem comum, e de gloria da pátria" (Niterói, 1836).

Dedicada às "ciências, letras e artes", diferentemente das revistas precedentes, a Niterói propunha-se a apresentar um quadro do desenvolvimento da sociedade brasileira sob o prisma das artes, das letras e da economia, além de esforçar-se em afirmar a existência de uma literatura nacional. Considerada pela historiografia da literatura precursora do romantismo no Brasil, para além de constituir-se em um marco apenas convencional, encontra-se em suas páginas uma interpretação do Brasil como nação independente, não mais pelo olhar estrangeiro, mas pelo de seus patrícios, jovens estudantes brasileiros residentes na capital francesa.

Os redatores Domingos José Gonçalves de Magalhães (1811-1882), Manuel de Araújo Porto Alegre (1806-1879) e Francisco Sales Torres Homem (18121876), poucos anos depois, de volta ao Brasil, apoiariam o projeto maiorista, integrariam a intelectualidade do Império e participariam das políticas do Estado Imperial, ingressando como sócios no Instituto Histórico e Geográfico Brasileiro. Na ocasião em que se encontravam juntos na capital francesa e escreviam a revista, propunham-se a compreender e identificar os "alicerces da Nação", o que reconhecia e legitimava, perante o exterior, o direito de existência do Brasil como país independente e, internamente, instigava a crença na comunhão de seus habitantes. ${ }^{6}$

Os futuros Visconde de Araguaia, Barão de Santo Angelo e Visconde de Inhomirim não precediam de famílias abastadas oriundas da aristocracia agrária. ${ }^{7}$ Eram filhos de comerciantes ou profissionais liberais que, através da dedicação ao estudo, às letras e à arte e, sobretudo, auxiliados pelas relações estabelecidas com os "grandes do Império", tornaram-se políticos, diplomatas e funcionários do Estado durante o reinado de Pedro II. Gonçalves de Magalhães e Sales Torres Homem, amigos desde a infância, formaram-se na Faculdade de Medicina do Rio de Janeiro, fundada por D. João VI, mas, frustrados com as perspectivas da carreira médica, foram aprofundar os estudos segundo suas verdadeiras aptidões. Araújo Porto Alegre, recém-chegado do Rio Grande do Sul ao Rio de Janeiro, onde estudaria pintura na Academia Imperial de Belas Artes, foi o primeiro a partir para a França, em 1832, acompanhando seu mes- 
tre e professor de pintura histórica, Jean-Baptiste Debret, então licenciado por problemas de saúde.

Em Paris, Gonçalves de Magalhães buscou as aulas de filosofia eclética e economia política, ao passo que Francisco de Sales Torres Homem estudava direito na Universidade de Paris. Torres Homem, ainda muito jovem, esteve envolvido como jornalista, na Aurora Fluminense, com a causa dos moderados que estavam no centro do poder durante os primeiros anos da Regência, e na Sociedade Defensora da Liberdade e da Independência Nacional, da qual foi vice-presidente. Em sua viagem, foi auxiliado financeiramente por Evaristo da Veiga e, graças ao seu prestígio, designado secretário da legação brasileira em Paris, sob a chefia do conselheiro Luiz Moutinho de Lima Álvares e Silva, o que lhe permitiu manter-se no estrangeiro. Gonçalves de Magalhães sobrevivia como preceptor do filho de um comerciante brasileiro em Paris e, uma vez sem emprego ou pensão, foi amparado pelo Ministro Plenipotenciário, o conselheiro José Joaquim da Rocha, até obter em 1835 a indicação para adido na legação brasileira, cargo que lhe proporcionou segurança financeira. Araújo Porto Alegre foi igualmente ajudado por Evaristo da Veiga e José Joaquim da Rocha em sua viagem e estadia e, a despeito das dificuldades financeiras que relatava em sua correspondência, teve a oportunidade de estudar pintura e arquitetura com renomados professores e artistas.

A França vinha se estabelecendo, desde a época dos philosophes e das Luzes, como centro difusor de ideias combativas e ousadas. Na cultura, nos costumes, na etiqueta, no vestuário e nos livros, Paris, com sua efervescente atividade científica e literária, musical e artística, tornou-se o lugar para onde os letrados iam direta ou indiretamente beber conhecimentos e inspiração. ${ }^{8}$ Mais do que isso, como nos lembra Marco Morel, a França era um centro de formação, "uma espécie de 'metrópole cultural' para estes mesmos grupos letrados que constituíam, também, os quadros dirigentes nacionais de cada país" (Morel, 2005, p.37).

Em Paris, à época, encontravam-se algumas das mais célebres instituições de ensino europeias. Era uma capital em ebulição, com crescimento populacional, com seus subúrbios onde os operários e trabalhadores se amontoavam, onde a miséria e as grandes contradições sociais davam sinais. Era uma metrópole cosmopolita, com proletariado crescente que já apresentava os sintomas da industrialização e do "mal du siècle". Palco dos acontecimentos mais dramáticos da história contemporânea, das jornadas revolucionárias e das conquistas constitucionais de 1789, seguidas pelo Terror Jacobino, sede do governo imperial de Napoleão Bonaparte, Paris deveria inspirar admiração e temor 
nos coetâneos, especialmente nos visitantes estrangeiros, diante da iminência das revoltas e das barricadas que tiveram lugar em 1830 ao se derrubar Carlos $\mathrm{X}$, último descendente dos Bourbon. Paris simbolizava todos os antagonismos e materializava todos os fantasmas da nova civilização emergente: do conservadorismo monárquico ao radicalismo libertário.

Mas, superados os grandes traumas do período jacobino, os acontecimentos revolucionários de 1830 e a implantação da Monarquia Parlamentar, apoiada por financistas e industriais, a França representava igualmente um modelo de moderação a ser seguido, como expressa este artigo nas páginas da Aurora Fluminense:

Os Bourbons, nunca ensinados nem pela desventura, nem pela prosperidade, deixaram de uma vez o solo da França, que tinham afligido com sua presença aborrecida, e uma nova era começou para os franceses. Porém, nesta rápida revolução, que mudou totalmente a face do governo de um grande povo; que moderação, que doçura, que generosidade! Nenhum excesso manchou a vitória; e se comparamos este acontecimento com as cenas lúgubres de que o mesmo país foi teatro nos anos de 1790 a 1794, nós abençoaremos o adiantamento que tem tido a moralidade e inteligência humana nestes últimos 40 anos, e os dons sociais que uma filosofia doce e filantrópica tem sabido derramar entre os povos... ${ }^{9}$

Próximo da proposição conciliatória do jornal de Evaristo da Veiga, os redatores da revista Niterói estariam no "centro dos acontecimentos". Nutrindose da filosofia que inspirava os liberais, distantes das ameaças de sedição, dos embates da política partidária e da sucessão regencial, porém cientes das "comoções da nossa Pátria", ${ }^{10}$ os estudantes brasileiros refletiam sobre a restauração da unidade e da ordem que pareciam temporariamente ameaçadas, até mesmo em razão da crise que se instalou durante a Regência do padre Feijó, liberal moderado que foi apoiado em 1835 pelo grupo de Evaristo da Veiga. Araújo Porto Alegre comentava em uma carta a Evaristo da Veiga as turbulências do período que "longe de me augurarem mal, ao contrário me dão pressentimento de um futuro brilhante; as nações, como os homens, necessitam de experiência, uma torrente de vicissitudes forma quadros comparativos, e, destes, grandes resultados" (Porto-Alegre, 1932, p.93-94). Assim, faltava apenas quem explicasse coerentemente tais "experiências", de forma a tornar claro o caminho a seguir em direção ao "futuro brilhante" da jovem nação pressentido pelo pintor, papel este que caberia à intelectualidade brasileira.

Cercados por tantos monumentos e "coisas raras" - "templos góticos", 
"arcos de triunfo, sobre colunas de bronze" e sobre palácios grandiosos -, os estudantes brasileiros nutriam suas inteligências com professores e livros, ${ }^{11}$ frequentavam salas de aula que se achavam sempre "apinhoadas", onde eram ensinadas "quantas línguas vivas há aí vivas e mortas", em que havia cadeiras para todas as ciências e suas subdivisões e outras "só para explicar Dante, Tucídides, Voltaire, Locke" (Lopes, 1964, p.19). Enquanto Porto Alegre se aperfeiçoava com as aulas do barão Gross, Gonçalves de Magalhães acompanhava vários cursos de uma só vez - direito, economia política e química (Lopes, 1964, p.20) - e frequentava aulas de Direito Natural de Théodore Simon Jouffroy, na Universidade de Letras de Paris (Lopes, 1964, p.26), interessado na filosofia eclética, a "filosofia do tempo", que gozou de muito prestígio na França durante a Monarquia de Julho e cujo maior representante foi o influente Victor Cousin.

Paris não prometia apenas a formação universitária aos seus visitantes, oferecia a boemia, o teatro, as danças, ${ }^{12}$ os salões onde se podia conhecer escritores e artistas. Diante de tantas atividades, o dispêndio era grande e a incerteza de obter proventos e trabalho levava principalmente Porto Alegre e Gonçalves de Magalhães a receber com gratidão o auxílio dos amigos.

O governo de Luís Felipe correspondeu a um período particularmente próspero para os estudos históricos, em função da necessidade de legitimação do novo regime através da conciliação, na história nacional, da memória da monarquia e da Revolução Francesa. ${ }^{13}$ Sob o ministério do historiador François Guizot, ocorreu a aproximação com os intelectuais, ${ }^{14}$ promoveu-se o estabelecimento de museus nacionais e institutos, a conservação do patrimônio arquivístico, incrementou-se o ensino em todos os níveis. Nessa época, ao lado do prestigioso Institut de France, ocorreu a fundação do Instituto Histórico de Paris durante o ano de 1833, associação dedicada aos estudos históricos, por iniciativa de Eugène de Monglave. Autor de algumas obras de História, Monglave era amigo do imperador Pedro I, conhecedor da língua portuguesa, grande entusiasta e estudioso dos assuntos brasileiros, o que o levou a proferir aulas sobre literatura brasileira na Sorbonne. Ao criar o Institut Historique, ao qual se filiou uma gama de literatos e intelectuais de diferentes especialidades, alguns dos quais já prestigiados historiadores na década de 1830, seu objetivo era criar um campo ilimitado de pesquisa, apartidário, tolerante quanto a escolas, sistemas ou opiniões diversas. ${ }^{15}$

Por intermédio de Eugène de Monglave, que se tornou secretário perpétuo da instituição, ocorreu a inserção dos brasileiros no Institut Historique de Paris. Assim, Gonçalves de Magalhães, Araújo Porto Alegre e Sales Torres 
Homem estavam entre os primeiros brasileiros a constar nas atas do Instituto, nas várias classes de história: Magalhães estaria na classe de História das línguas e das literaturas; Porto Alegre, na de História das belas artes, e Torres Homem, na classe de História das ciências sociais e políticas. Assíduos e entusiasmados no período entre 1834 e 1836, sentiam-se prestigiados por ingressar como sócios de um Instituto que, conforme consideravam, lançaria seus nomes à posteridade (Lopes, 1964, p.29-30). Partindo desse pressuposto, indicaram algumas personalidades para sócios, como o padre e orador Monte Alverne, mestre de Gonçalves de Magalhães, e o pintor Jean-Baptiste Debret, autor de Voyage Pittoresque au Brésil, que havia criado no Brasil a Escola de Belas Artes e que divulgou na capital francesa as novidades relacionadas ao extenso Império dos trópicos, sobre o qual pouco se conhecia.

Entre as várias atividades de pesquisa e divulgação do saber conferidas aos sócios do Instituto estava a leitura e discussão de memórias durante as sessões. Apesar da participação discreta nas polêmicas no Institut, a exposição de trabalhos configurou-se em uma experiência muito importante, que se expressaria pouco depois nas páginas da revista Niterói. Contagiados pelos debates sobre questões éticas, nacionais, estéticas e culturais que acabavam ocorrendo, os três amigos produziram memórias que foram lidas perante as classes e publicadas no primeiro volume do Journal de l'Institut Historique, entre junho e julho de 1834. O Brasil, para os franceses, era "apenas conhecido na Europa culta como um vasto e maravilhoso deserto habitado por selvagens antropófagos" ${ }^{16}$ apesar dos esforços de viajantes e pintores estrangeiros, como Langsdorff, Spix e Martius, Rugendas e Debret. Interessava-lhes, contudo, conhecer profundamente os costumes, paisagens e populações do Brasil no âmbito do estreitamento das relações diplomáticas e de comércio com as excolônias, ocorrido a partir da Restauração.

As memórias, reproduzidas nas páginas do Journal, desiguais em termos de extensão e aprofundamento de informações, analisavam os efeitos do jugo colonial sobre as artes, letras e ciências, justificando o atraso cultural e civilizacional, desde o Descobrimento até o século XIX. Afirmavam a existência do potencial criador dos habitantes do Brasil desde a época colonial, a despeito das interdições impostas pela metrópole portuguesa, afirmando os progressos ocorridos nas últimas décadas, e constatavam que estariam intimamente ligados à organização de uma nova cultura com base na influência francesa.

Dispondo de poucos documentos e informações seguras acerca da biografia de escritores dos séculos anteriores e de seu próprio século, Gonçalves de Magalhães anunciava sua intenção em escrever uma História literária do 
Brasil, empreendimento inédito, uma vez que haveria um "vazio de produções" sobre o tema. ${ }^{17}$ Sua história da literatura, que consistia em apreender o sentido do desenvolvimento das letras no Brasil ao longo das épocas, inspirava-se claramente no Resumée de L'Histoire Litteraire du Brésil (1826), de Ferdinand Denis. Entretanto, pretendia, sobretudo, afirmar a existência de 'gênios' no Brasil: "O brasileiro nascia poeta e músico: no alto de suas altas palmeiras, ao som de uma mandolene agreste, seu espírito se exprime em acordes melodiosos, como uma brisa de suas florestas virgens" (Magalhães, 1994, p.47).

Justificava, porém, a ausência de grandes autores e a estagnação literária no período colonial pela influência do classicismo, das "divindades gregas e romanas" que "sacrificavam a beleza de uma natureza original" (Magalhães, 1994, p.47). Os melhores escritores, mesmo que em certa medida inspirados pelo classicismo, teriam surgido no fim do século XVIII - Santa Rita Durão, Basílio da Gama, o padre Gonzaga, Sousa Caldas, São Carlos. Essa preocupação com os 'gênios' nacionais, tão recorrente ao longo de seus ensaios e poesias, justifica-se em um contexto no qual o discreto incremento da educação faz surgir o intelectual leigo, ao passo que a figura do intelectual vinculado ao clero e aos antigos gêneros literários, como os sermões, a retórica e a poesia épica, perde sua força. Ao mesmo tempo, a falta de reconhecimento da sociedade e dos dirigentes, diante de sua relevância social, torna necessário inseri-lo em uma tradição de grandes autores, enfatizando uma continuidade entre as gerações intelectuais. O próprio Magalhães se insere nessa tradição de escritores nacionais, pois encaminhou ao Instituto um livro de poemas de sua autoria do período de 1829 a 1834 .

Se Magalhães apontou, nessa resumida comunicação, para a insuficiência da cultura letrada no período colonial, Sales Torres Homem constatou igualmente os efeitos repressores e inibidores do sistema colonial. Sua tese é de que a nação foi "forçada a ficar imóvel em todos os elementos de humanidade e de se absorver profundamente na unidade de um despotismo sistematicamente opressor" que prejudicou o avanço das ciências no Brasil, carecendo este país, ao longo de três séculos, de academias ou instituições literárias (Magalhães, 1994, p.47-48). A despeito disso, constatava a existência de poesia "Em meio ao mutismo da inteligência popular, no seio do despotismo da metrópole", inflamada pela beleza da natureza, e destacava poetas que, desde o século XVII, enfrentavam a censura e o jugo dos vice-reis e capitães gerais e não podiam chorar o tormento ou cantar a liberdade da pátria (Magalhães, 1994, p.48).

Torres Homem elegeu a Revolução Francesa como a ruptura do jugo colonial, quando esta engendrou a "fuga da Corte de D. João" para o Brasil. Em 
sua avaliação, as grandes transformações tiveram início naquele momento, que marcava a aparição das ciências no Brasil, atraindo médicos, matemáticos, naturalistas e literatos de todos os pontos de Portugal. O impulso teria sido dado pela criação de instâncias para a formação e o aperfeiçoamento das inteligências, como a transferência da Academia de Marinha para o Rio de Janeiro, consagrada às ciências matemáticas, às ciências físico-matemáticas e ao estudo de artilharia, à navegação e ao desenho; uma Academia militar para ensinar matemáticas, ciências militares e naturais, e duas Escolas médico-cirúrgicas, no Rio de Janeiro e na Bahia. Esse avanço da instrução pública promovido por D. João teria esbarrado no receio do progresso das luzes, mas permitiu à juventude brasileira dispor, em sua própria pátria, de meios de instrução, por mais imperfeitos que fossem, sem gastar fortunas ou ter de cruzar o Atlântico.

No terceiro e mais recente período da história das ciências no Brasil, decorrente da emancipação, Torres Homem aponta a criação de cadeiras de "bellasletras" nas instituições de ensino, a fundação de duas escolas de Direito - em São Paulo e Pernambuco -, a reforma das Academias médico-cirúrgicas e sua transformação em faculdades espelhadas no modelo francês. Enfim, salienta que a despeito do atraso, teriam aflorado sábios no século XIX - como José Bonifácio de Andrada, filólogo e mineralogista; o doutor Mello Franco, autor de trabalhos de medicina na Academia de Lisboa; frei Leandro do Santíssimo Sacramento, ilustre botanista, idealizador da cultura do chá no Brasil; o erudito Silva Lisboa, autor de escritos sobre legislação comercial, e os eloquentes padres São Carlos e Sampaio -, todos apontados como exemplos de ilustração científica (Magalhães, 1994, p.48). Assim como Magalhães, prevê um futuro promissor para o "gênio natural" do povo brasileiro, livre dos entraves que se opunham por muito tempo a seu desenvolvimento e que resultavam da presença do elemento português (Magalhães, 1994, p.49).

A “Memória”, lida por Araújo Porto Alegre no Instituto Histórico de Paris, relata de maneira entusiástica e mais detalhadamente as conquistas obtidas após a Independência. Propondo-se a "mergulhar no passado" e lançar um rápido olhar sobre a marcha das artes da pátria, o autor apontou o período colonial como época dos primórdios das artes no país. Porém, o artista negava aos índios originalidade poética e artística, as quais apareceriam entre os colonos e depois com os jesuítas, que arregimentariam artistas para a construção de igrejas e capelas e para a composição de quadros e baixos-relevos.

Porto Alegre também esclarecia a seus ouvintes do Institut sobre os motivos do atraso da marcha das artes, atribuindo-os ao governo português que, em dois séculos, restringiu-as aos seus domínios, a ponto de nenhum templo 
ou obra ser desenhado ou executado no Brasil: “Ao brasileiro só restava juntar as peças; era proibido aplicar suas faculdades intelectuais para as artes mecânicas mais grosseiras" (Magalhães, 1994, p.50). A utilização pelos colonos portugueses dos braços africanos, tanto na mineração como nos lazeres derivados do luxo trazido pelo enriquecimento, teria levado muitos escravos a aprenderem música ou pintura e a receberem salário. Porto Alegre nega habilidades artísticas aos indígenas, embora as atribua aos africanos e mulatos que decoraram a igreja de São Francisco no Rio de Janeiro, ergueram conventos e pintaram quadros sobre a reconquista de Pernambuco aos holandeses e sobre a derrota de Villegagnon. Se o governo despótico não impedia as artes, embora a condição colonial tivesse legado ao país o desprezo pelo artista, o progresso maior teria ocorrido com a transferência da Corte (Magalhães, 1994, p.50).

Porto Alegre, tal qual Torres Homem, associava a Revolução Francesa e sua repercussão na América ao impulso dado à cultura, especialmente pela presença do estrangeiro e pela entrada de livros, que teria acelerado ainda mais suas disposições nacionais. Ao mencionar o “estrangeiro”, Porto Alegre excluía os artistas lusitanos que acompanhavam D. João, pois estes "não se elevavam acima da mediocridade", tendo os talentos brasileiros supremacia incontestável sobre os portugueses. Porto Alegre referia-se aos músicos italianos que chegaram em 1815 para compor a orquestra da Capela real e, sobretudo, aos artistas franceses recrutados pelo marquês de Marialva - Lebreton, Debret, os irmãos Taunay, Grandjean de Montigny, Ovide, os irmãos Ferrez, Pracher e o músico Neucon -, que chegaram às vésperas da coroação.

Assim, conforme a interpretação do discípulo de Debret, a poesia e a música caminhariam à frente, em direção ao progresso, pois teriam se libertado da imitação da Antiguidade. Entraves ao desenvolvimento da arte atrasaram a instalação da Academia de Belas Artes e fizeram-se sentir através de intrigas "para fechar a carreira ao talento", resguardando os privilégios dos artistas portugueses, seguida pela dispersão dos franceses. Referindo-se à época contemporânea, o autor sustentava que a Independência havia marcado a retomada do desenvolvimento da literatura e da arte, quando a Academia foi fundada e o corpo acadêmico empossado, a partir do que "novos projetos se preparavam", a capital se embelezava e "o brasileiro reconhecia nascer no coração uma simpatia pela França”. O Rio de Janeiro, capital do Império tropical, palco de exposições, cidade agraciada pela arquitetura de Grandjean de Montigny e pela pintura de Debret, merecera admiração dos seus habitantes e ganharia, graças a eles, a cada dia em elegância e regularidade (Magalhães, 1994, p.50-51).

Dando conta da situação presente, o autor comunicava aos sócios a conti- 
nuação do trabalho de Debret, membro do Institut, justificando que a despeito de todas as dificuldades, das falhas nos estatutos da Academia, da falta de recurso e de amparo aos alunos, o pintor demonstrara notável bravura ao formar doze alunos e ajudá-los também com recursos pecuniários, estabelecendo laços fortes de união entre mestre e discípulos (Magalhães, 1994, p.52). Segundo o artista brasileiro, a história nacional foi traduzida em "poesia muda" pelos discípulos de Debret - Francisco Pedro de Amaral, pintor e arquiteto; Christo Moreira; Simplício Rodrigues de Sá, José dos Reis Arruda e o próprio Porto Alegre, que viera a Paris aperfeiçoar-se nas belas artes (Magalhães, 1994, p.52).

Magalhães constatava, assim, o desenvolvimento da arte no Brasil e a mudança de mentalidade em relação ao artista, registrando o aumento do número de escolas e academias e o aumento do ordenado dos professores (Magalhães, 1994, p.53). Ele apresenta essa mudança da seguinte forma em sua "Memória":

Nesta época, uma prodigiosa revolução se manifesta nas ideias do povo brasileiro: os pintores, que até agora não eram apreciados, são admitidos nas sociedades mais brilhantes; eles aproveitavam a estima e a consideração geral; o imperador parou sua carruagem no meio das ruas para se entreter com os pintores; um deles deixa escapar seu pincel no momento de inspiração; o imperador se abaixou, o recolhe e entrega a ele. Enfim as belas artes se espalham nas famílias e são raras hoje aquelas em que o desenho e a música não entram na educação das crianças. (Magalhães, 1994, p.52)

A imagem do imperador se abaixando e entregando o pincel ao pintor, demonstrando respeito e admiração, omite, contudo, as enormes dificuldades financeiras e a precariedade da formação e subsistência do artista, literato e poeta na sociedade oitocentista. O preconceito ligado à figura do poeta e do pintor seria resultado do desinteresse das classes proprietárias e do Estado em financiar atividades vistas em geral como improdutivas e dispensáveis. Nas cartas de Porto Alegre e Magalhães ao frei Monte Alverne é possível entrever essa percepção mais crítica e pessimista acerca do lugar reservado às letras e às artes na sociedade brasileira (Lopes, 1964). Porém, o esforço da "Memória” em afirmar a mudança, percebendo a marcha irreversível em direção à civilização, era importante para confirmar o intercâmbio cultural com a França, tanto que acabou sendo incorporada ao terceiro volume da obra Voyage Pittoresque et Historique au Brésil, ou séjour d'un artiste française au Brésil, depuis 1816 jusqu'en 
en 1831 inclusivement, de Debret, publicado em 1839. Porto Alegre concluía desta maneira sua "Memória":

Em definitivo senhores, posso dizê-lo com orgulho que, as belas artes acharam no Brasil um solo fértil; a Escola de Rio de Janeiro, filha legítima da Escola de Paris, lhe ofereceria tão logo os filhos dignos dela, em toda a parte uma sede de instrução que não pode ser saciada a não ser pelas fontes da ciência. Também, veja a juventude brasileira socorrer as pragas do Oceano, solicitar o exílio como um favor, vencer tempestades para tocar o solo da França, e lá se remetendo ao trabalho com um novo ardor, consultar noite e dia estes preciosos tesouros que vossa hospitalidade proporciona a todas as nações do globo. (Magalhães, 1994, p.52)

De forma geral, as três “Memórias" identificavam como externas as razões para o atraso cultural e afirmavam que o país reunia os atributos necessários para progredir, isto é, gênio e natureza exuberante. Convivendo no ambiente do Instituto Histórico de Paris, Sales Torres Homem, Domingos Gonçalves de Magalhães e Araújo Porto Alegre sentiram como sua missão traçar um panorama sociocultural mais amplo do país e oferecê-lo ao Instituto Histórico de Paris. Isto ocorreu no retorno da viagem de Magalhães e Araújo Porto Alegre à Itália, entre 1834 e 1836. Nasceu, então, a ideia da criação da revista Niterói, que teria por modelo, certamente, o Journal de l'Institut Historique e, provavelmente, as revistas literárias do período, como a francesa Revue des Deux Mondes. Ao ser finalizado no mês de junho, o primeiro número do primeiro tomo de 187 páginas foi noticiado na revista do Instituto Histórico de Paris, e o segundo número, com 262 páginas, foi lançado no semestre seguinte.

Sem tipografia própria, preços de vendas, assinaturas, subscrições ou patrocínio estatal, o empreendimento foi financiado pelos próprios redatores ${ }^{18}$ com o auxílio de um negociante brasileiro residente em Paris, o que denota o caráter amador e pouco comercial da publicação. ${ }^{19} \mathrm{O}$ primeiro número teve seus textos publicados em " 12 folhas em $8^{\circ}$, bem distribuídos, bem variados, cheios de pensamentos e de fatos" (Monglave, 1836, p.5), contendo, abaixo do título "Nitheroy, revista brasiliense sciencias, lettras, e artes", a epígrafe "Tudo pelo Brasil e para o Brasil” e uma ilustração litográfica de esferas armilares e instrumentos de medição sobrepostos representando o saber científico. Foi impresso por Beaulé e Jubin e comercializado na então modesta livraria de Auguste Fonatine e M. Dauvin, localizada na movimentada Passage du Panorama, especializada em livros luxuosos e modernos, que se tornaria prestigio- 
sa e forneceria livros para a Corte de Luís Felipe. Nessa casa Magalhães pusera à venda seus poemas Suspiros poéticos e saudades, naquele mesmo ano.

Com uma tiragem reduzida, a primeira edição já esgotara no primeiro mês e circulou entre os sócios do Institut - os exemplares provavelmente foram presenteados aos conhecedores da língua portuguesa e interessados em assuntos relacionados ao Brasil, como o presidente do Institut, Michaud; o pintor Jean-Baptiste Debret; o secretário perpétuo da instituição, E. Monglave, e o escritor Ferdinand Denis, entre outros -, assim como entre a comunidade brasileira de Paris. A intenção inicial dos redatores era lançar uma revista mensal; contudo, o projeto foi interrompido quando Magalhães foi demitido da legação por divergências ideológicas com o chefe Luís Moutinho e, sem condições de permanecer na França, retornou ao Brasil no fim de 1836.

Conforme indica a apresentação da revista, dirigida "Ao leitor", seus redatores avaliavam que faltava aos segmentos letrados, aos bacharéis e dirigentes dedicação ao estudo e empenho na produção de obras literárias e artísticas que projetassem o país. Mais do que informar, encontra-se explicitada a ação pedagógica dos idealizadores da revista ao "apresentar em um limitado espaço considerações sobre todas as matérias que devem merecer a séria atenção do Brasileiro amigo da glória nacional" (Niterói, 1836).

Dentre os assuntos abordados nos dois números estariam astronomia, física industrial, química, filosofia da religião, resenhas e poesias. Sales Torres Homem escreveu três artigos sobre economia politica - "Considerações econômicas sobre a escravatura", "Reflexões sobre o crédito público e sobre o relatório do Ministro da fazenda" e "Comércio do Brasil" -, além de uma resenha a respeito de Suspiros poéticos e saudades, de Gonçalves de Magalhães. Quanto à literatura, dois artigos foram publicados - o primeiro, de Gonçalves de Magalhães, intitulado "Ensaio sobre a história da literatura do Brasil", e outro, de João Manuel Pereira da Silva, "Estudos sobre a literatura" -, enquanto Araújo Porto Alegre enveredava por outro ramo das artes em seu ensaio "Ideias sobre a música".

Folheando o primeiro número, o leitor depara com um artigo redigido por Sales Torres Homem, que deixa claro o papel da Niterói como formadora da opinião. Em "Considerações Econômicas sobre a Escravatura", o autor desenvolveu o argumento de que a escravatura é e sempre foi responsável pelo atraso e decadência dos povos. Demonstrava essa tese através de estudo sério e exposição do pensamento de vários autores que trataram de economia política e da ciência política, a maioria franceses, como Jean Baptiste Say e Aléxis de Toqueville. Preocupando-se em embasar e referenciar suas observações e 
opiniões historicamente, mostrou como, desde o estabelecimento dos colonos na América, onde deveriam "semear os germes da vindoura civilização", os portugueses marcaram sua presença com os horrores da conquista, a espoliação e o extermínio dos aborígines e, ulteriormente, com a escravização e o tráfico africano, que persistiu por três séculos.

Torres Homem demonstrou o argumernto de que a escravidão não era mais lucrativa do que o trabalho livre e que acarretou, ao longo da história, consequências negativas para a produtividade e o avanço da agricultura e, principalmente, para a indústria, como a desvalorização das classes livres e o preconceito quanto às profissões assalariadas e as artes mecânicas. Estas foram por muito tempo restritas aos escravos africanos, que não teriam habilidade para o trabalho na indústria por "incapacidade", "preguiça", "relutância e vida desordenada” (Niterói, 1836, p.39).

Assim, as ponderações de Sales Torres estavam em sintonia com as transformações socioeconômicas que ocorriam no Velho Mundo. O jovem diplomata orientava a classe proprietária do Brasil sobre o caminho a seguir, tomando como modelo as sociedades modernas onde predominariam a indústria, $o$ acréscimo de riquezas, oficinas, máquinas a vapor e bancos, por exemplo. Com o avanço das ideias e dos costumes e o progresso da reflexão, deveriam rejeitar "a desarmoniosa e imoral exploração do homem pelo homem", entendendo que o destino inevitável da humanidade e da civilização é o trabalho livre.

O ponto de vista liberal de que a escravidão era um entrave no caminho da civilização era compartilhado pelos outros redatores que, ao lado da base material do processo, em seus artigos tratariam do "mundo moral" (Niterói, 1836, p.216), assim como dos motivos do atraso cultural do país: “A Literatura nacional e as Artes que vivificam a inteligência, animam a indústria e enchem de glória e orgulho os povos, que as cultivam" (Niterói, 1836, p.6). Como afirmou o padre e orador Francisco de Monte Alverne em um de seus discursos perante o primeiro imperador, as letras e as artes constituiriam os "alicerces indestrutíveis" sobre os quais o Brasil deveria estabelecer sua existência. ${ }^{20} \mathrm{~A}$ Niterói foi redigida dentro do espírito de construir esses firmes alicerces, a fim de que a independência política conquistada fosse preservada e que o Brasil assegurasse sua existência como nação. Restituiriam, através da história, as raízes e potencialidades culturais do 'povo', ampliando e elaborando as observações do "Resumé", publicado no Journal de l'Institut Historique de Paris.

Também no primeiro número, em artigo intitulado "Ensaio sobre a história da literatura do Brasil, um estudo preliminar”, Gonçalves de Magalhães assim definiu o destino de uma nação livre: "Jamais uma Nação poderá prever 
o seu futuro, quando ela não reconhece o que ela é, comparativamente com o que foi. Estudar o passado, é ver melhor o presente, é saber como se deve marchar" (Niterói, 1836, p.145). Marchar, para o autor, significava "engrandecer-se, é desenvolver todos elementos de civilização". Faltava, assim, ao país, além de cultuar as ciências, as letras e a indústria (Niterói, 1836, p.146), valorizar seus literatos e instituir uma tradição literária autônoma, separada da portuguesa.

Em seu ensaio o poeta anunciava não pretender traçar a biografia cronológica dos escritores que povoaram a história do Brasil, mesmo porque não dispunha de muitos dados empíricos (Lopes, 1964, p.59). Outrossim, retomava na história "a tradição viva dos homens, de como se passaram as coisas", pois, "seguindo a marcha do desenvolvimento intelectual, e pesquisando o espírito que a presidia, poderemos livremente mostrar, não acabado, mas ao menos verdadeiro quadro histórico da nossa literatura" (Niterói, 1836, p.135). Contudo, as questões que propõe verificar, a origem, o progresso da literatura, as condições em que floresceram os poetas, revelam a importância atribuída aos escritores individuais, o que reflete a concepção de que "a glória de uma nação não é senão um reflexo da glória de seus grandes homens” (Niterói, 1836, p.139).

Sendo assim, compreende-se seu esforço em mostrar que na colônia os gênios eram 'sepultados em vida', envergonhavam-se de serem brasileiros, sufocados pela vida rústica, pela escravidão e pelo jugo colonial português. Mais tarde, por influência dos portugueses, os poetas se colocariam a copiar a mitologia grega, ao invés de inspirar-se em sua própria natureza, religião e costumes: "em parte deve sobre nós recair a censura, que tão pródigos somos em louvar, e admirar os estranhos, quão mesquinhos nos mostramos para com os nossos, e deste jeito visos damos de que nada possuímos" (Niterói, 1836, p.144). O estabelecimento da Corte, a Independência e a abdicação de Pedro I, teriam aberto uma nova época para as letras no país que, com o auxílio francês, começaram a se libertar da imitação de uma civilização estrangeira. Ficava claro, portanto, que para o autor a emancipação política permitia aflorar uma literatura já existente, embora incipiente, intimamente ligada ao solo e aos habitantes do Brasil.

Partindo do entendimento de que "cada povo tem sua Literatura, como cada homem o seu caráter, cada árvore o seu fruto" (Niterói, 1836, p.131), o poeta utilizou-se da metáfora orgânica, familiar ao idealismo alemão e ao romantismo, para afirmar sua especificidade. ${ }^{21}$ Ao considerar a literatura um fruto, um produto orgânico e natural, pensaria nela como única e singular, ainda que resultasse da mescla de duas culturas diferentes (Niterói, 1836, p.133- 
134). O autor a define como caráter ou "expressão de um povo e de uma época”, do que há de mais sublime, belo e heroico (Niterói, 1836, p.131-132) e ao mesmo tempo é "variável como são os séculos" (Niterói, 1836, p.134), pois se encontraria sujeita a modificações através do tempo. A literatura, tomada por Magalhães de forma abrangente, aplicada a todas as ciências e artes, sempre correspondeu ao caráter e ao estado de civilização de um povo, assim como a poesia teria favorecido seu desenvolvimento (Niterói, 1836, p.158). Ela tanto seria produto das ideias que predominavam em uma sociedade, quanto expressaria, da forma mais autêntica, como seria uma sociedade em toda a sua especificidade material, moral e espiritual, em suas falhas, em seu atraso e em seu progresso.

O fio condutor da argumentação de Magalhães parece-nos advir da leitura dos alemães e de sua interpretação pelos franceses - Madame de Stäel e Victor Cousin, entre outros. Um referencial que está ora implícito, ora explicitado no texto é aquele de Herder, precursor de uma filosofia da história, que também perpassa os textos de Porto Alegre, "Ideias sobre a Música”, e de João Manuel Pereira da Silva, "Estudos sobre a Literatura", qual seja, o historicismo. O historicismo surgiu nas décadas de 1760-1770, em meio à preponderância do racionalismo na época do Iluminismo, atribuído ao professor italiano Giambattista Vico (1668-1744) e ao teólogo alemão Gotfried Herder (17441803). Os filósofos divergiam da concepção de História que tornava seu objetivo a comprovação de leis naturais para o gênero humano e que, para tanto, submetia os fatos singulares. Na crítica de Vico à interpretação iluminista, o fato histórico individual e a variedade histórica deveriam ser objetos de uma nova e autônoma ciência do homem e da sociedade, integrada a uma nova ciência da natureza.

O pensamento de Herder restringiu-se, a princípio, à Alemanha, até que no século XIX, sob o romantismo, teve grande impacto sobre a geração de letrados do período pós-revolucionário, especialmente na França, onde o mesclaram com certas concepções liberais. Herder concebia a pluralidade de naturezas humanas, a variedade de valores, assim como a singularidade das situações humanas. Estabelecia o relativismo cultural contra o anacronismo presente nas filosofias da história creditadas em seu tempo, e não atribuía proeminência a nenhum povo ou época sobre os demais. ${ }^{22}$

Uma das mais relevantes reflexões de Herder dizia respeito à nação e à sua transformação no tempo. As nações corresponderiam a graus ou momentos de um desenvolvimento único do espírito do mundo e da humanidade. Nutrindo-se da tradição pietista luterana, Herder entendeu que, tal como o 
indivíduo, a nação também teria uma alma, que seria ao mesmo tempo natural e absolutamente individual e singular, obscura, vital e irracional, ${ }^{23}$ que traduziria sua própria individualidade e se distinguiria por valores próprios e intransferíveis. Ela se constituiria em uma forma de vida completa, autossuficiente, da qual a singularidade do indivíduo humano se tornaria inseparável. Essa alma não se expressaria nos círculos cultivados, intelectuais e cosmopolitas, mas nos costumes dos camponeses, aqueles que foram estigmatizados como rudes e ignorantes pelos filósofos esclarecidos (Antoni, 1963, p.54), de onde emanariam a poesia, a linguagem e os cantos populares, as fábulas e costumes, expressões coletivas e anônimas, que seriam ao mesmo tempo originais, sinceras e espontâneas, ingênuas e livres de quaisquer convenções.

Tal qual o desenvolvimento biológico individual, a história das nações seria cíclica - passando por infância, maturidade e velhice. Para Herder, cada período se construiria sobre o período seguinte, e o progresso humano seria mensurável pela percepção “do que veio antes" e "do que virá depois”, e então exibiria variações de acordo com a circunstância cultural (Hamilton, 1996, p.41). Ao lado disso, Herder pensava a história da humanidade, similar à história sacra, em que cada etapa do seu desenrolar seria também um momento de revelação progressiva de uma verdade absoluta, de acordo com uma ordem preestabelecida pela Providência.

Esse novo conceito de nação romântica, que Herder deu à Alemanha e à Europa, foi vitoriosamente legado ao século XIX. Favorável à nação, mas hostil ao Estado, o pensador alemão ambicionava realizar uma História cultural da humanidade, pretensamente apolítica, como supunha ser sua filosofia da história. A nação, apesar de alicerçar-se sob o plano político no Estado, não era representada como política (Antoni, 1963, p.54), no que seu pensamento diferia de concepções historicistas posteriores simpáticas aos Estados-nacionais. A concepção do historicismo alemão sobre as nações, entendidas como organismos vivos que teriam seu espírito próprio, sua história particular e sua alma profunda e irracional, cuja voz seria o 'espírito' do povo, encontrou-se com o movimento intelectual do romantismo.

Esse movimeno intelectual elegeu o espírito como o elo entre a subjetividade, destacada pelos filósofos e escritores, e o universo exterior - a comunidade cada vez mais dilacerada pelos conflitos religiosos, políticos e sociais. A concepção filosófica do romantismo alemão reabilitou o sujeito substancial, ao considerar o indivíduo como o finito, o efêmero e temporal, inserido no infinito, ${ }^{24}$ na totalidade, e assim a individualidade aparece como uma zona de passagem (Gusdorf, 1984, p.46). A consciência dessa transitoriedade é a 
revelação do infinito no finito, manifestação de uma verdade e uma tensão que irrompem de dentro do homem para o mundo (p.47). Contudo, tal consciência de si, de sua singularidade em relação aos demais, pode ser alcançada por cada um através da experiência, que necessariamente emerge dentro de um contexto histórico (p.43, 46).

Em virtude dessa distinção e também da localização do indivíduo em um habitat sócio-histórico, o sentimento de nacionalidade surge como uma expressão do eu, uma vez que o indivíduo estaria ligado ao seu povo (Volk) e, portanto, partilharia ao longo do tempo de crenças e suposições, habilidades, sentimentos e experimentos preexistentes com todo o círculo familiar, a comunidade local e a nação. ${ }^{25}$

O sentimento nacional se expressava na restauração de tradições nacionais e no estudo das línguas antigas, com o objetivo de descrever características 'naturais' das comunidades, antes de serem corrompidas pela civilização, e assumia sua forma mais radicalizada nos movimentos nacionalistas de libertação durante as guerras napoleônicas e na Primavera dos Povos, em 1848. Por isso, esse sentimento relaciona-se com o despertar das culturas literárias nacionais na Alemanha, na Rússia, na Polônia, na Hungria, nos países escandinavos e em outras partes, com a afirmação da língua, das artes e das tradições nativas, frente a uma cultura aristocrática e cosmopolita, compartilhada tanto pelas classes dirigentes locais como pelos invasores franceses.

Enfim, Herder fornecia a base para se pensar as nações recém-fundadas após a independência, uma vez que o historicismo se apresentava como uma teoria da nação e da história nacional (Ortiz, s.d., p.9) em que, para compreender sua individualidade e indivisibilidade, a despeito de toda forma de dominação e segmentação, era preciso compreender as realidades e tradições populares, pois seria possível encontrar nelas o substrato de uma autêntica cultura nacional. ${ }^{26}$

Assim, o ensaio de Magalhães consistia no esforço por compreender essa individualidade e indivisibilidade. Era igualmente uma busca pelos motivos implícitos do desenvolvimento ulterior dos destinos nacionais: "Como nós estudamos a história, não com o único fito de conhecer o passado, mas sim para tirarmos úteis lições para o presente..." (Niterói, 1836, p.159). Por isso, se a erudição, a coleção de documentos raros e a comprovação dos fatos eram procedimentos importantes que motivavam seus esforços, seu objetivo principal era tanto restabelecer a originalidade e a particularidade dos artefatos da nação, quanto interpretar o curso da sua história no que diz respeito à cultura nacional, desvinculando-a de questões e conflitos políticos que poderiam di- 
vidir e opor seus habitantes. Assim, a ideia da nação como uma unidade orgânica, fenômeno único nos aspectos espacial e temporal, pressupunha que elementos culturais, costumes, usos, religião, língua, arte, folclore e mitos formariam uma totalidade harmônica, constituiriam um sistema de instituições e valores, organicamente entrelaçados, que corroboraria a si mesmo. ${ }^{27}$ Embora não houvesse na Niterói uma reflexão mais atenta a respeito do Estado, a noção de nação endossava um projeto que preconizasse a autonomia política, a unidade territorial e a construção de um Estado que encarnasse as tradições e os valores nativos.

Em sintonia com essas ideias historicistas, no "Ensaio sobre a história da literatura do Brasil” Gonçalves de Magalhães considerava que cada época representaria então uma ideia "que por uma espécie de contágio ... lavra entre os homens de uma época; reunem-se todos n'uma mesma crença; seus pensamentos se harmonizam e para um só fim tendem" (Niterói, 1836, p.134). Inspirado por Victor Cousin, que realizava a leitura de filósofos alemães e a sintetizava em sua filosofia eclética, o poeta defendia que a ideia que preside, "contém e explica as outras ideias" é o espírito de uma época, "razão oculta nos fatos contemporâneos" (Niterói, 1836, p.134).

Essa 'ideia' se manifestaria em todos os elementos de cultura, configurando o caráter particular de determinada sociedade. Compartilhando dessa mesma convicção, Araújo Porto Alegre em seu ensaio sobre a música pretendia igualmente apreender um sentido geral para a evolução das artes, da música e poesia na história (Niterói, 1836, p.174). Para ele a música seria a "vida e a alma da sociedade", que sem corporeidade, em todos os tempos e lugares, desde o estado selvagem até a civilização, exprimiria paixões nutridas por ideias, como saudade, patriotismo e heroísmo, e estabeleceria a relação entre Deus e os homens (Niterói, 1836, p.164). Cultivada e apreciada por grandes homens ao longo da história, de Platão a Pedro I, a música teria evoluído da infância à decadência dos povos. Como afirmava que o caráter dos diferentes povos manifestar-se-ia em suas produções artísticas, realçado na Música, propunha que olhássemos não para a história da música, mas para o estado das nações presentes, para comparar suas produções musicais e sua civilização. À medida que crescesse a indústria, com ela viria a perfeição musical (Niterói, 1836, p.171-174).

No Brasil, os melhores talentos das províncias viriam exercitar sua arte na capital do Império, que representaria a transformação cultural pela qual passava o país recém-independente, com a promessa de um futuro mais próspero para as artes e os artistas. Com seu teatro de canto, sua capela Imperial, 
aclamada por ser um dos melhores conservatórios de música do mundo, o Império modificou o gosto musical. Teriam surgido, então, entre a Colônia, o Reino e o Império, músicos como Marcos Portugal, seu colega Pedro Teixeira e Francisco Manoel, "homens de gênio", que produziram continuamente composições musicais (Niterói, 1836, p.182-183). O autor assinalava, contudo, que a arte da música estaria em decadência no país depois da derrubada da Capela Imperial (Niterói, 1836, p.182) e que só se regeneraria através da influência e da inspiração de "gênios estrangeiros" (Niterói, 1836, p.173-174).

Desde os estudos de Herder, a língua teve grande destaque entre as manifestações culturais (Antoni, 1963, p.54), o que se reflete no interesse pela gramática, pela linguística e pelos cantos populares. Em especial a poesia, considerada a expressão do sentimento autêntico e espontâneo da alma de um povo, e que deveria estar, portanto, livre de regras e convenções (Antoni, 1963, p.4). A poesia foi o pivô de toda crítica romântica aos racionalistas no século XVIII e embasou a querela entre defensores dos clássicos e dos românticos. Contudo, a língua e a literatura tiveram papel ainda mais significativo no processo de afirmação das nações recém-constituídas:

Que uma literatura nacional existia, ao lado de uma língua justificava que reclamassem a independência e a unidade nacional, sobretudo quando outros direitos históricos e outras premissas etno-políticas faziam falta ... E mesmo lá onde este argumento faltava, o folclore, a tradição etnográfica, os cantos, as danças, os costumes, lendas, tomavam o valor de testemunhos e o título à independência. (Antoni, 1963, p.56)

Portanto, ao realizar um ensaio pioneiro sobre a literatura de sua terra, Magalhães cumpria um dever moral como historiador e como educador, imbuído de uma 'nobre missão'. A literatura nacional, como as artes, não seria mais concebida como prazer ou ornamento. Assim, revestiu-se de dignidade e seriedade, e sua história transformou-se na "história espiritual de uma nação" (Antoni, 1963, p.56). O autor avaliava que quando um "povo desaparece com todas as suas instituições, crenças e costumes, a literatura escapa ao tempo para anunciar às futuras gerações qual foi o caráter desse povo" (Niterói, 1836, p.132). Seguindo os passos do ensaio de Gonçalves de Magalhães, Pereira da Silva em seu "Estudos sobre a literatura", no segundo número da Niterói, analisava a marcha da literatura (que compreendia a filosofia, a escrita da história e a poesia) desde os egípcios até a derrocada da poesia imitativa do classicismo e a vitória da poesia moderna, dita romântica. Escrevia que o literato, que no 
Brasil precisaria ser mais valorizado, deveria ser a expressão do pensamento do povo, "intérprete" e conhecedor de suas superstições, crenças obscuras e secretas (Niterói, 1836, p.216).

O literato, como o historiador, conforme afirmava Gonçalves de Magalhães, deveria "melhor conservar os monumentos dessa glória para as raças futuras a fim de que não nos exprobem nosso desmazelo... e de bárbaros não nos acusem" (Niterói, 1836, p.137). Ao aludir aos "monumentos dessa glória”, ele se referia, como era corrente ainda no século XIX, aos documentos, vestígios e testemunhos de uma cultura, produzidos, evidentemente, por um grupo social que aspirava eternizar e naturalizar determinada representação da realidade. Como afirmou Jacques Le Goff: "O documento é monumento. Do esforço das sociedades históricas para impor ao futuro - voluntária ou involuntariamente - determinada imagem de si próprias" ${ }^{28} \mathrm{O}$ emprego dos dois termos como sinônimos - monumento com sentido de 'recordação', designando igualmente grandes coleções de documentos, até a imposição do termo 'documento' no final do século XIX, e documento entendido como 'prova' - evidencia que tanto um como o outro são utilizados pelo poder e são produtos da sociedade que os fabricou segundo determinadas relações de força. ${ }^{29}$

O século XIX é época da consagração dos monumentos históricos, em que os historiadores se dedicavam a defender a preservação dos monumentos e edifícios contra a sede de demolições do Estado sob a Revolução Industrial, por entender que os edifícios e monumentos antigos seriam ilustrativos do sentimento nacional, passando a simbolizar a nação. A concepção tradicional do ofício do historiador era então de "memorizar os monumentos do passado e transformá-los em documentos” (Le Goff, 1992, p.546). Dessa forma, “conservar os monumentos" significaria também produzir esses documentos, recuperando os feitos e a biografia de 'gênios', e restituir a glória à sociedade de onde eram originários. Como explicitava Gonçalves de Magalhães, fazia-se necessário "reunir todos os títulos de sua existência, para tomar o posto que justamente lhe compete na grande liga social, como o nobre recolhe os pergaminhos de sua genealogia para em face do Rei fazer-se credor de uma graça" (Niterói, 1836, p.144).

Essa era certamente a intenção dos redatores e colaboradores da Niterói, como nos faz supor a correspondência enviada por Debret ao discípulo Araújo Porto Alegre, recém-chegado ao Rio de Janeiro e nomeado seu sucessor na cadeira de professor de pintura histórica da Academia Imperial de Belas Artes. Entre outras coisas, o pintor francês recomendava: 
Eu sempre insisto que conserve a ideia fixa de se tornar o historiógrafo do Brasil! Honra, pouco comum, que recai nas suas atribuições; e que associa o artista ao herói que ele representa; reproduzindo inteligivelmente, aos olhos do mundo inteiro uma biografia nacional comprovada em um museu aberto à admiração dos estrangeiros, atraídos até o momento somente pela riqueza dos produtos da história natural ou o exotismo dos ornamentos dos selvagens do Brasil. ${ }^{30}$

E acrescentava à recomendação:

O Brasil existe, ele precisa de monumentos primitivos de sua história, para completar o interesse que ele é chamado a inspirar, um dia, como nação distinta.

Esta coleção reproduzida por um simples traço, tomará lugar, entre os documentos históricos, nas bibliotecas europeias. (Debret, 1837)

Em época na qual ainda não se processara a institucionalização da disciplina e a afirmação de uma comunidade profissional, o escritor, o erudito e o historiador possuíam estatutos muito próximos ${ }^{31}$ e podiam exercer as mesmas atividades. Debret associava a função do 'artista' à do 'historiógrafo', ambos comparáveis a heróis, capazes de registrar, preservar e compor um quadro da sociedade e dos costumes, e de produzir inteligivelmente aos olhos do mundo uma 'biografia nacional'.

Contudo, Gonçalves de Magalhães deparava com a dificuldade de encontrar 'monumentos primitivos' que se constituíssem como 'documentos históricos'. Acreditava que os indígenas, Tamoios, Caetés e Tupinambás, primeiros habitantes do Brasil, eram músicos e poetas, inspirados pela natureza nativa, e que seus cânticos haviam influenciado a atual cultura, como os cânticos do "Bardo da Escócia" haviam influído sobre a poesia do Norte da Europa (Niterói, 1836, p.152). Exposto à pedagogia jesuítica e ao jugo tirânico do colonizador, o 'precioso monumento' desses 'povos incultos' desapareceria com o passar do tempo (Niterói, 1836, p.157).

Com base nessa noção de monumento, perceptível em vários textos de escritores do século XIX, como Alexandre Herculano nos ensaios "Qual é o estado da nossa literatura? Qual é o trilho que ela hoje tem que seguir?” e "Monumentos pátrios", os livros, a língua e as manifestações culturais eram monumentos, testemunhos da continuidade histórica e da identidade de um povo e precisavam ser descobertos, restituídos ou produzidos quando não existissem. Preferencialmente relacionavam o que denominamos atualmente como a 'alta cultura', obras como A ilíada para os gregos ou Os lusíadas para os 
portugueses, que não deixariam de expressar o caráter e a singularidade da coletividade e da época que as produziram.

Compartilhando dessa convicção, Magalhães e Araújo Porto Alegre insistiam em correspondência trocada com Monte Alverne, em março de 1834, para que mandasse publicar seus sermões e seu curso de lógica em francês, pois seus "excelentes sermões" seriam "considerados como monumentos de eloquência e de língua portuguesa” (em Lopes, 1964, p.26). Em carta de janeiro de 1836 a Monte Alverne, Magalhães dizia: "insisto sobre isso porque não quero que se perca este monumento de glória de nossa pátria; quando tão poucos escrevem fôra triste que aqueles que o fazem não deixem sinais de si” (em Lopes, 1964, p.63).

Diante de uma sociedade que até pouco tempo antes satisfazia-se com a oralidade, encontrando-se tão carente de grandes obras e de grandes autores, cujos escritores eram raramente traduzidos para o francês e permaneciam praticamente desconhecidos na Europa, o sacrifício se fazia necessário para cravar o nome na posteridade e projetar o Brasil como nação. O próprio Magalhães anunciava seu intento de dispor de suas economias e garantir notoriedade ao fazer publicar os poemas que compôs durante a longa viagem à Itália. A publicação sairia naquele ano de 1836, sob o título de Suspiros poéticos e saudades, deixando entrever que a distância entre o esquecimento e a posteridade residia no dispêndio de alguns contos de réis. $\mathrm{Na}$ busca de obras que expressassem a 'alma nacional', e não a imitação servil, o tão esperado livro de poesias mereceu de Pereira da Silva uma menção em seu artigo "Estudos sobre a literatura”. $\mathrm{Na}$ nota de rodapé acrescentava que "este livro é um monumento de glória erigido ao Brasil, um monumento verdadeiramente nacional e poético" (Niterói, 1836, p.239-240).

No intuito de "regenerar" a pátria e livrá-la das chagas do passado colonial, os três literatos julgaram fundamental garantir a publicação de "monumento verdadeiramente nacional e poético", que fosse um documento necessariamente original da cultura brasileira. A literatura antiga e moderna poderia formar, com as artes, a religião e os costumes, as raízes mais profundas e longínquas da nacionalidade, e juntos representariam os alicerces da nação. A condição de civilização acompanhava o estabelecimento de uma tradição intelectual que buscava produzir determinada memória coletiva para a comunidade, a qual permitisse atender à recomendação de Debret de fazer o Brasil figurar como nação distinta. Isso compreendia esquecer os conflitos, as dissenções políticas e as desigualdades, e recordar os grandes homens do passado e suas obras, 
criando uma identificação entre indivíduo e comunidade nacional, entre passado e presente, projetando-os em direção a um futuro promissor.

\section{NOTAS}

${ }^{1}$ CHARLE, Christophe. "La Presse de la Monarchie de Juillet". In: Le siècle de la presse (1830-1939). Paris: Seuil, 2004. p.28-34.

${ }^{2}$ BENOIT, Denis. Literatura e engajamento: de Pascal a Sartre. São Paulo: Edusc, 2002. p.177.

${ }^{3}$ RODRIGUES, Ernesto. "Revistas Literárias". In: BUESCU, Helena Carvalhão. Dicionário do Romantismo Português. Lisboa: Caminho, 1997. p.472.

${ }^{4}$ MOREL, Marco. As transformações dos espaços públicos. São Paulo: Hucitec, 2005. p.122.

${ }^{5}$ VIANNA, Hélio. Contribuição à historia da imprensa. Rio de Janeiro: Imprensa Nacional, 1945. p.98. Durante a estada da Corte, também traziam seções literárias os jornais Variedade ou ensaios de literatura da Bahia (1812) e o Patriota (1813 e 1814). No Primeiro Reinado os Anais Fluminenses de Ciências, Artes e Literatura, de 1822, o Jornal Científico, Econômico e Literário, de 1826, a Revue Brésilienne e o Beija-Flor, de 1830. Na Regência, a Revista da Sociedade Filomática, em 1833.

${ }^{6}$ ANDERSON, Perry. Nação e consciência nacional. São Paulo: Ática, 1989. p.14.

${ }^{7}$ PINASSI, Maria Orlanda. Três devotos, uma fé, nenhum milagre. São Paulo: Unesp, 1998. p.40.

${ }^{8}$ MOISÉS, Massaud. "Paris, berço do Romantismo brasileiro: Gonçalves de Magalhães e Araújo Porto-Alegre". Revista Brasileira, Rio de Janeiro, n.43, ano XI, abr.-jun. 2005. p.67.

9 "Seção Interior", de 9 fev. In: Aurora Fluminense, Rio de Janeiro: Typographia Gueffier, n.447, p.1884, 1831.

${ }^{10}$ PORTO-ALEGRE, M. A. "Correspondência de Manuel de Araújo Porto Alegre a Evaristo da Veiga de 8 de maio de 1834". In: Revista da Academia Brasileira de Letras, Rio de Janeiro, v.39, p.93-94, 1932.

${ }^{11}$ MAGALHÃES, D. J. G. "Carta a Monte Alverne datada de 20 de janeiro de 1834". In: LOPES, Roberto (Org.). Cartas a Monte Alverne. São Paulo: Conselho Estadual de Cultura, 1964. p.15-21.

${ }^{12}$ Em Carta a Evaristo da Veiga, Porto Alegre diz ter se cansado de Paris, lugar atraente para quem gosta de vadiação, teatros e dança. PORTO-ALEGRE, M. A. "Carta escrita a Evaristo da Veiga em maio de 1834". In: Revista da Academia Brasileira de Letras, v.39, 1932.

${ }^{13}$ FURET, François. A oficina da História. Lisboa: Gradiva, 1997. p.124-125.

${ }^{14}$ DEBRET, Jean Baptiste. "Carta a Araújo Porto Alegre datada de 7 de junho de 1842". Seção de Manuscritos da Biblioteca Nacional, Rio de Janeiro. 
${ }^{15}$ Esta é a proposição do projeto de regulamento do Instituto Histórico de Paris. Apud FARIA, Maria Alice. Brasileiros no Instituto Histórico de Paris. São Paulo: Conselho Estadual de Cultura, s.d. p.18.

${ }^{16}$ Niterói, revista brasiliense, Paris: Libraire Dauvin et Fontaine, n.2, 1836. p.184.

${ }^{17}$ MAGALHÃES, D. J. Gonçalves de. "Resumé de l'histoire de la littérature, des sciences et des arts au Brésil" (Journal de l'Institut Historique). In: Discurso sobre a história da literatura do Brasil. Rio de Janeiro: Fundação Casa de Rui Barbosa, 1994. p.47.

${ }^{18}$ MONGLAVE, E. "Relatório lido na 2a classe do Instituto Histórico". In: Niterói, revista brasiliense, Paris: Libraire Dauvin et Fontaine, n.2, 1836. p.5.

${ }^{19}$ RODRIGUES, E. “Formas de viver em 1836”. In: BAREL, Ana Beatriz Demarchi. Revista Nitheroy. Coimbra: Minerva Coimbra, 2006. p.9.

${ }^{20}$ Discurso de Monte Alverne em 25 de março de 1831. Apud: LOPES, Hélio. A divisão de águas: contribuição ao estudo das revistas românticas, Minerva Brasiliense (1843-1845) e Guanabara (1849-1856). Tese (Doutorado em História) - FFLCH/USP. São Paulo, 1972. p.66-67.

${ }^{21}$ Como explica Gusdorf: "A árvore romântica é parábola de identidade e de comunidade vital, indicadora de uma ordem natural mais essencial que as construções arbitrárias do espírito". GUSDORF, Georges. Fondements du savoir romantique. Paris: Payot, 1982. p.438.

${ }^{22}$ HAMILTON, Paul. Historicism. London: Routledge, 1996. p.35; CASSIRER, E. A filosofia do Iluminismo. Campinas: Unicamp, 1998. p.307; CASSIRER, Ernst. "La eclosión del Historicismo". In: .El Problema del Conociemento. México: Fondo de cultura econômica, 1993. v.IV, p.271.

${ }^{23}$ ANTONI, Carlo. L'Historisme. Genève: Librarie Droz, 1963. p.53, 58.

${ }^{24}$ GUSDORF, G. L'Homme romantique. Paris: Payot, 1984. p.43.

${ }^{25}$ WATT, Ian. Mitos do individualismo moderno. Rio de Janeiro: Zahar, 1997. p.190.

${ }^{26}$ ORTIZ, Renato. Românticos e folcloristas. São Paulo: Olho d'água, s.d. p.22.

${ }^{27}$ FLEISHMAN, Avrom. The English historical novel, Walter Scott to Virginia Woolf. London: The John Hopkins Press, 1972. p.19.

${ }^{28}$ LE GOFF, Jacques. “Monumento/documento". In: História e memória. São Paulo: Unesp, 1992. p.548.

${ }^{29}$ Ibidem. "Memória". In: Enciclopédia Einaudi. Porto: Imprensa Nacional - Casa da Moeda, 1997. p.17.

${ }^{30}$ DEBRET, Jean Baptiste. "Carta de Debret a Porto Alegre datada de 28 de agosto de 1837”. Seção de Manuscritos da Biblioteca Nacional, Rio de Janeiro.

${ }^{31}$ NOIRIEL, Gerard. Sur la "crise" de l'historie. Paris, Berlin Éd., 1996. p.68.

Artigo recebido em fevereiro de 2009. Aprovado em outubro de 2009. 